\title{
Root wood anatomy of 14 Brazilian Cerrado species
}

\author{
Anatomía de la madera de raíz de 14 especies del Cerrado Brasileño
}

\author{
Eduardo Luiz Longui a*, Juliana Arce de Goes Pacheco a, Sandra Monteiro Borges Florsheim a, \\ Gabriela Trindade Pires a, Julia Sonsin-Oliveira ${ }^{\text {b* }}$ \\ *Corresponding author: ${ }^{a}$ Instituto Florestal, Divisão de Dasonomia, R. do Horto 931, \\ CEP 02377-000, São Paulo, SP, Brazil, jsonsin@yahoo.com.br, edulongui@gmail.com \\ b Universidade de Brasília - UNB, Campus Universitário Darcy Ribeiro, Instituto de Ciências Biológicas, \\ Asa Norte, CEP 70910-900, Brasilia, DF, Brazil.
}

\begin{abstract}
SUMMARY
Studies on root wood anatomy are scarce, mainly due to the lack of commercial interest and the difficulty to collect. In Brazilian Cerrado, local craftsmen use root wood for marquetry, the manufacture of such small items as lampshades or ornaments, and table bases. However, taxonomy based on root wood can serve as a guide toward the conservation and management of tree stocks in urban environment. Therefore, we herein describe the root wood anatomy of 14 tree species that occur in the Brazilian Cerrado. To accomplish this, we studied samples from main sinker root, at a depth of about $20 \mathrm{~cm}$, from 37 trees aged 5 to 10 years. Anatomical procedures followed the standard techniques for preparation and analyses of wood samples. We used stem or branch samples from other studies to carry out anatomical description and comparison. However, we encountered some problems, such as: difficulty to distinguish growth rings, sample processing and, in some cases, sample description, since quantity, distribution and type of axial parenchyma differed substantially from that of the main stem. Nonetheless, we did find a variation in the presence/absence of septate fibers among the samples, and noted differences in ray composition.
\end{abstract}

Key words: Cerrado species, tropical wood, wood identification, xylem anatomy.

\section{RESUMEN}

Los estudios sobre la anatomía de la madera de raíz son escasos, principalmente por la falta de interés comercial y la dificultad de recolección. En el Cerrado brasileño, los artesanos locales utilizan la madera de raíz para la marquetería, la fabricación de objetos pequeños como pantallas de lámparas o adornos, y la base de la mesa. Sin embargo, la taxonomía basada en la madera de raíz puede servir como una guía para la conservación y el manejo de las reservas de árboles en entornos urbanos. Por lo tanto, se describió la anatomía de la raíz de la madera de 14 especies de árboles que se encuentran en el Cerrado brasileño.

Se estudiaron muestras de la raíz principal, a una profundidad de aproximadamente $20 \mathrm{~cm}$, de 37 árboles de 5 a 10 años. Los procedimientos anatómicos siguieron las técnicas estándar para la preparación y el análisis de muestras de madera. Se utilizaron muestras de tallo o rama de otros estudios para llevar a cabo la descripción anatómica y la comparación. Sin embargo, se encontraron algunos problemas, tales como: los anillos de crecimiento difíciles de distinguir; además, era problemático procesar la muestra y, en algunos casos, describirla dado que la cantidad, distribución y tipo de parénquima axial difería sustancialmente de la del tallo principal. No obstante, se encontró una variación en la presencia/ausencia de fibras septadas entre las muestras, y también diferencias en la composición de los radios.

Palabras clave: especies de Cerrado, madera tropical, identificación de madera, anatomía del xilema.

\section{INTRODUCTION}

Cerrado represents a vast tropical savanna ecoregion of Brazil, and woody species in this region are used by local populations for fuel and charcoal (Ratter et al. 1997). Local craftsmen are known to use root wood for marquetry, as well as for the manufacture of such small items as lampshades or ornaments. According to Krause et al. (2010), the scarcity of xylem research at root level can be explained by the lack of commercial interest. Besides, because it is generally time-consuming and often costly (Maeght et al. 2013). However, apart from the use of root wood in crafts, the knowledge of root anatomy, irrespective of vegetation, can be very useful in instances where roots are the only evidence of such environmental crimes as deforestation. In urban settings, an analysis of roots following damage to underground pipes may help identify the offending trees from others.

Studies of root wood anatomy gain more prominence when comparisons are made between root wood and stem 
wood regarding anatomy, wood properties, hydraulic conductivity and wood properties along axial variation within the tree. Such studies expand our knowledge of how such a variation occurs and the physiological and mechanical impact of such differences (Caldwell et al. 1998, Machado et al. 2007, Pratt et al. 2007, Longui et al. 2012, 2017, Fortunel et al. 2014, Marcati et al. 2014).

We acknowledge the difficulties involved in collecting samples of root wood in Cerrado species because of their sheer depth. Hence, the wood anatomy of roots from Cerrado species are largely unexplored, in addition many papers are focused in comparative wood anatomy (root versus stem or branches) and have only been reported on shrubs or small trees (Machado et al. 1997, Machado et al. 2007, Longui et al. 2012, 2017, Goulart and Marcati 2012, Marcati et al. 2014, Goulart et al. 2015).

Except for Eriotheca gracilipes roots studied by Longui et al. (2012) and Anadenanthera peregrina, Copaifera langsdorffi, Handroanthus ochraceus, Ocotea corymbose and Xylopia aromatica roots studied by Longui et al. (2017), this is the first time we have a complete description for root anatomy of the selected species. Therefore, the present study contributes to fill a gap, especially by describing the root wood anatomy of 14 tree species that occur in the Brazilian Cerrado.

\section{METHODS}

Experimental area. The study was carried out in the Cerrado area of Assis State Forest (2234'19" S, 50²3'32" W, ele- vation 588 m), Assis, São Paulo. The soil in this region has low organic matter, although good water permeability. The climate is Cwa by the Köppen classification. Warm with dry winters, it is characterized by mean annual temperature of $20-25{ }^{\circ} \mathrm{C}$ (average minimum temperature of $18{ }^{\circ} \mathrm{C}$ ) and average annual rainfall of $1,441.5 \mathrm{~mm}$ (CEPAGRI 2016). The dry season falls between April and September. Water deficit in April is -1.6 (sum of water deficit $\mathrm{mm}$ ) and in August, it is $-1.2 \mathrm{~mm}$.

Collection of samples. We collected samples from 37 selected trees aged 5 to 10 years, comprising 14 tree species (table 1). We measured height and stem diameter at breast height (1.3 $\mathrm{m}$ from the ground) from each tree. To obtain root samples about $20 \mathrm{~cm}$ from the main sinker root, selected trees were uprooted. For standardization, anatomical studies were carried out on the wood portion adjacent to the cambium. Samples of $1.5 \mathrm{~cm}^{3}$ were cut from each disc.

Transverse and longitudinal radial and tangential sections, approximately 15 to $20 \mathrm{~mm}$ thick, were obtained. Sections were bleached in a solution of sodium hypochlorite and distilled water (50\%) and afterwards double-stained with aqueous $1 \%$ safranin and aqueous $1 \%$ astra blue (1:9) (Bukatsch 1972), followed by dehydration in an alcoholic series and, finally, passed through butyl acetate. To obtain cells dimensions, preparations of wood macerates were done according to Franklin's method (1945, modified by Kraus and Arduim 1997) and stained with aqueous $1 \%$ safranin dye (Bukatsch 1972). Anatomical descriptions were based on the IAWA Committee (1989), for each fea-

Table 1. Studied species, number of samples, tree height and diameter at breast height (DBH).

Especies estudiadas, número de muestras, altura del árbol y diámetro a la altura de pecho (DAP).

\begin{tabular}{llccc}
\hline \multicolumn{1}{c}{ Family } & \multicolumn{1}{c}{ Species } & No samples & $\begin{array}{c}\text { Height } \\
(\mathrm{m})\end{array}$ & $\begin{array}{c}\text { DBH } \\
(\mathrm{cm})\end{array}$ \\
\hline Annonaceae & Xylopia aromatica (Lam.) Mart. & 4 & 4.2 & 4.8 \\
Bignoniaceae & Handroanthus ochraceus (Cham.) Mattos & 5 & 2.9 & 4.3 \\
Erythroxylaceae & Erythroxylum tortuosum A. St.-Hil. & 1 & 2.8 & 4.9 \\
Fabaceae-Caesalpinoideae & Copaifera langsdorffii Desf. & 5 & 4.0 & 4.5 \\
Fabaceae-Mimosoideae & Anadenanthera peregrina var. falcata (Benth.) Altschul & 3 & 3.4 & 5.6 \\
& Stryphnodendron adstringens Benth. & 2 & 3.0 & 5.1 \\
Lauraceae & Ocotea corymbosa (Meisn.) Mez. & 5 & 4.0 & 4.0 \\
Malvaceae & Eriotheca gracilipes (K. Schum.) A. Robyns. & 3 & 3.6 & 6.1 \\
Melastomataceae & Miconia albicans (Sw.) Triana. & 1 & 4.8 & 4.9 \\
Myrtaceae & Myrcia bella Cambess. & 2 & 4.1 & 8.1 \\
& Eugenia aurata O. Berg. & 2 & 1.9 & 3.5 \\
Ochnaceae & Eugenia punicifolia (Kunth) DC. & 2 & 3.1 & 2.9 \\
Vochysiaceae & Ouratea spectabilis (Mart.) Engl. & 1 & 2.1 & 2.8 \\
\hline
\end{tabular}


ture $\mathrm{n}=25$ was used initially, except for the pits, where $\mathrm{n}$ $=10$ was adopted.

Qualitative and quantitative anatomical data were obtained with Image Pro Plus, v. 6.3, software attached to an Olympus CX 31 microscope.

\section{RESULTS}

Wood anatomical descriptions. Each species is described below and exemplified in figures 1-7; some details are in figure 8 . All the quantitative values will be given as average and $($ maximum $/$ minimum and standard deviation $=\mathrm{SD}$ ).

Xylopia aromatica. Growth rings: marked by thick-walled and radially flattened latewood fibers (figure 1A, detail). Vessels: diffuse porosity, solitary and multiple (figure 1A); $437 \mu \mathrm{m}(613 / 155 \mathrm{SD}=81)$ in length, 15 per square milli-

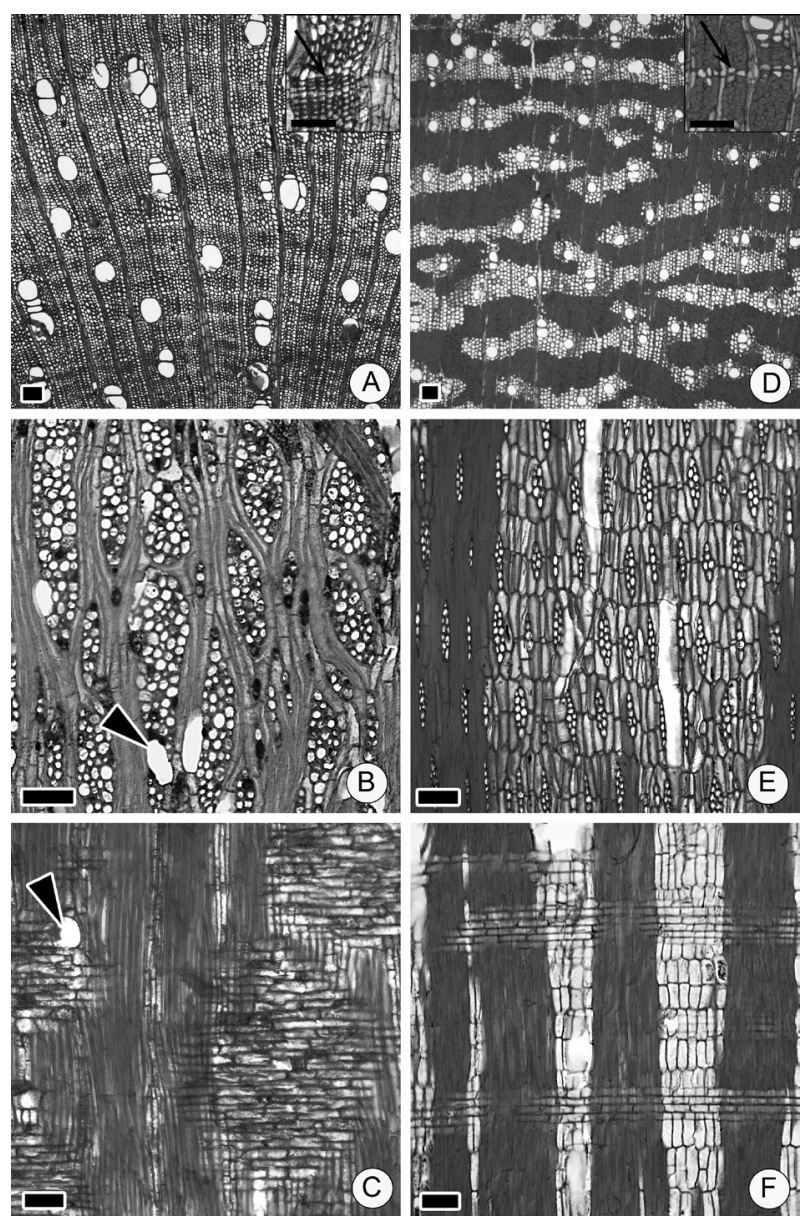

Figure 1. Root wood anatomical features of Xylopia aromatica (A-C); arrow points growth ring in A, detail; arrow points oil cell in $\mathrm{C}$; and Handroanthus ochraceus (D-F); arrow points growth ring in $\mathrm{D}$, detail. Scale bars $=100 \mu \mathrm{m}$; details $=50 \mu \mathrm{m}$.

Características anatómicas de la madera de raíz de Xylopia aromatica (a-c) y Handroanthus ochraceus (D-F). Barras $=100 \mu \mathrm{m}$; detalles $=50 \mu \mathrm{m}$. meter $\left(\mathrm{mm}^{-2}\right)(34 / 5 \mathrm{SD}=7), 79 \mu \mathrm{m}(137 / 31 \mathrm{SD}=25)$ in tangential diameter; simple perforation plate; intervessel pits alternate, circular; vessel-ray pits similar to intervessel pits in size and shape; few deposits. Fibers: with distinctly bordered pits (less than $3 \mu \mathrm{m}$ ) (figure $8 \mathrm{~A}$ ); thinto thick-walled; $880 \mu \mathrm{m}(1455 / 534 \mathrm{SD}=166)$ in length. Axial parenchyma: predominantly scalariform, and in irregular lines, sometimes reticulate (figure 1A); 2 to 5 cells per parenchyma strand. Rays: 1 to 6 cells wide (figure 1B); $462 \mu \mathrm{m}(1087 / 172 \mathrm{SD}=192)$ tall, $59 \mu \mathrm{m}(118 / 24 \mathrm{SD}=55)$ wide, $11 / \mathrm{mm}(16 / 5 \mathrm{SD}=2)$, all ray cells procumbent; body ray cells procumbent with one row of upright and/or square marginal cells (figure 1C); secretory elements: oil cells associated with ray and axial parenchyma (figure 1B,C, arrowread). Aggregate rays in 1B.

Handroanthus ochraceus. Growth rings: marked by marginal bands of axial parenchyma, sometimes more than 10 cells wide, and occasionally by lines (figure 1D, detail), high quantity of vessels adjacent to the growth layer can occur. Vessels: diffuse porosity; solitary and multiple vessels (figure 1D); $227 \mu \mathrm{m}(350 / 130 \mathrm{SD}=47)$ in length, 25 per square millimeter $\left(\mathrm{mm}^{-2}\right)(113 / 6 \mathrm{SD}=25), 79 \mu \mathrm{m}(130 / 38$ $\mathrm{SD}=18)$ in tangential diameter; simple perforation plate; intervessel pit alternate, circular; vessel-ray pits similar to intervessel pits in size and shape. Fibers: very thick-walled; $903 \mu \mathrm{m}(1354 / 294 \mathrm{SD}=270)$ in length; with simple to minutely bordered pits; gelatinous fibers may occur. Axial parenchyma: unilateral, short to long confluent forming irregular bands, lozenge-aliform and marginal bands (figure 1D); mostly with 2 to 4 , or rarely 6 , cells per parenchyma strand. Rays: 1 to 2 cells wide (figure 1E); $145 \mu \mathrm{m}$ $(293 / 66 \mathrm{SD}=33)$ tall, $18 \mu \mathrm{m}(36 / 7 \mathrm{SD}=5)$ wide, $6 / \mathrm{mm}$ $(14 / 3 \mathrm{SD}=2)$; all ray cells procumbent (figure $1 \mathrm{~F})$; perforated ray cells. Storied structure: axial parenchyma regularly storied; rays regular to irregularly storied (figure 1E).

Erythroxylum tortuosum. Growth rings: marked by fiber zones (figure 2A, arrow). Vessels: diffuse-porous; solitary and multiples (figure $2 \mathrm{~A}) ; 331 \mu \mathrm{m}(477 / 205 \mathrm{SD}=69)$ in length, 33 per square millimeter $\left(\mathrm{mm}^{-2}\right)(57 / 18 \mathrm{SD}=10)$, $73 \mu \mathrm{m}(88 / 60 \mathrm{SD}=8)$ in tangential diameter; simple perforation plates; intervessel pits alternate, circular; vessel-ray pits similar to intervessel pits in size and shape throughout and pits with many reduced borders to apparently simple, horizontal to vertical; tyloses; deposits. Fibers: fibers with distinctly bordered pits (figure $8 \mathrm{~B}$ ); very thick-walled; $763 \mu \mathrm{m}(952 / 538 \mathrm{SD}=104)$ in length; gelatinous fibers. Axial parenchyma: diffuse-in-aggregates, diffuse, unilateral and scanty paratracheal (figure 2A); 2 to 8 cells per parenchyma strand. Rays: 1 to 3 ray cells in width; $271 \mu \mathrm{m}$ $(477 / 205 \mathrm{SD}=45)$ tall, $35 \mu \mathrm{m}(46 / 25 \mathrm{SD}=5)$ wide, $10 / \mathrm{mm}$ $(14 / 5 \mathrm{SD}=2)$; uniseriate portion as wide as multiseriate portions (figure 2B); body ray cells procumbent with 2-4 rows of upright and/or square marginal cells and square and upright cells mixed throughout the ray (figure 2C). In- 
organic inclusions: prismatic crystals in chambered axial parenchyma cells and in ray cells.

Copaifera langsdorffii. Growth rings: marked by marginal bands of axial parenchyma (figure 2D, arrows). Vessels: diffuse-porous; solitary and multiple (figure 2D); $416 \mu \mathrm{m}(880 / 121 \mathrm{SD}=118)$ in length, 17 per square millimeter $\left(\mathrm{mm}^{-2}\right)(25 / 3 \mathrm{SD}=4), 83 \mu \mathrm{m}(215 / 35 \mathrm{SD}=30)$ in tangential diameter; simple perforation plate; intervessel pits alternate, circular, vestured; vessel-ray pits similar to intervessel pits in size and shape; deposits. Fibers: with simple to minutely bordered pits; thin- to very thickwalled; $891 \mu \mathrm{m}(1896 / 150 \mathrm{SD}=267)$ in length. Axial parenchyma: in bands, lozenge and short confluent; 2 to 4 cells per parenchyma strand (figure 2D). Rays: 1 to 5 cells wide (figure $2 \mathrm{E}) ; 299 \mu \mathrm{m}(1030 / 84 \mathrm{SD}=145)$ tall, $50 \mu \mathrm{m}(89 / 10 \mathrm{SD}=17)$ wide, $7 / \mathrm{mm}(10 / 4 \mathrm{SD}=1)$; all ray cells procumbent; body ray cells procumbent with one to two rows of upright and/or square marginal cells (figure $2 \mathrm{~F})$. Secretory structures: axial canal in long tangential lines (figure 2D - arrow head; figure 8C - arrow). Inorganic inclusions: prismatic crystals in chambered axial parenchyma cells.

Anadenanthera peregrina var. falcata. Growth rings: marked by axial parenchyma flattened cells and by flattened latewood fibers (figure 3A, detail). Vessels: diffuse-porous; solitary and multiples of three (figure $3 \mathrm{~A}$ ) and some up to six; $251 \mu \mathrm{m}(386 / 117 \mathrm{SD}=55)$ in length, 14 per square millimeter $\left(\mathrm{mm}^{-2}\right)(39 / 7 \mathrm{SD}=5), 90 \mu \mathrm{m}(211 / 55 \mathrm{SD}=35)$ in tangential diameter; simple perforation plates; intervessel pits alternate, circular, vestured; vessel-ray pits similar to intervessel pits in size and shape, and with many reduced
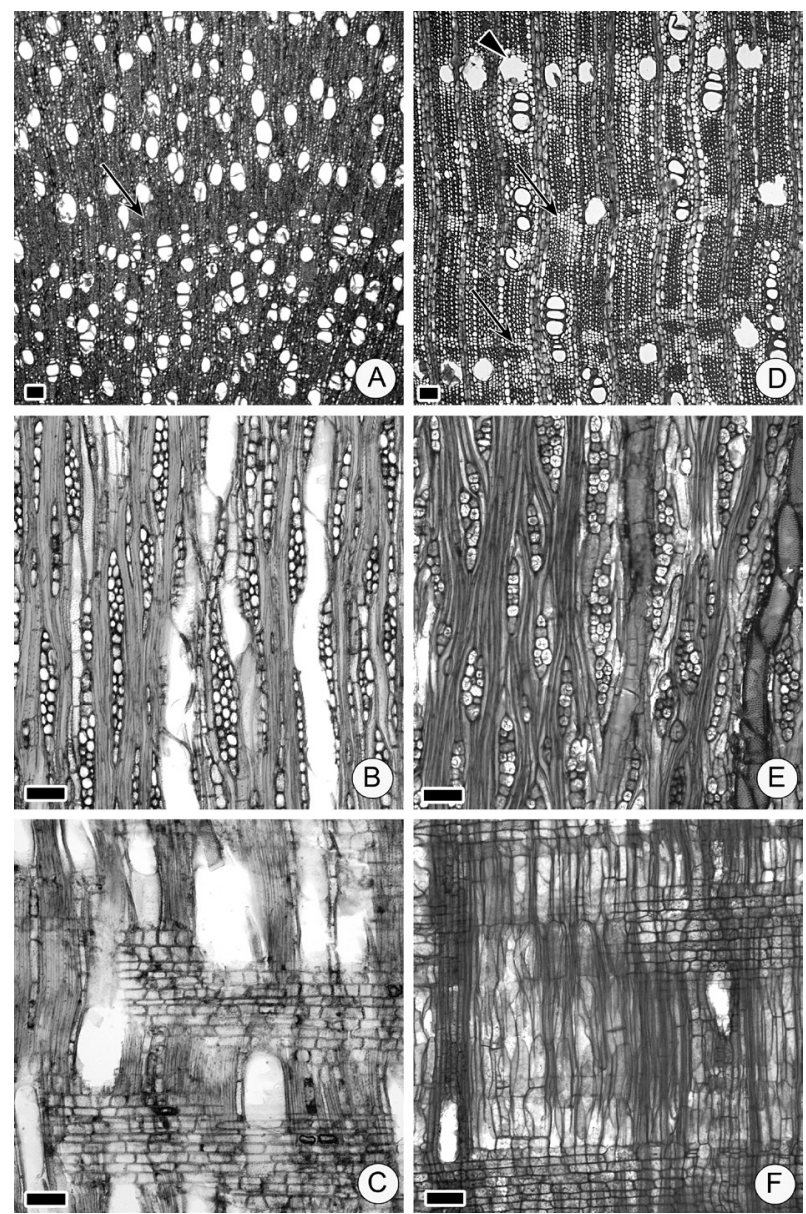

Figure 2. Root wood anatomical features of Erythroxylum tortuosum (A-C) and Copaifera langsdorffii (D-F); arrows point growth ring in $\mathrm{A}$ and $\mathrm{D}$, detail. Scale bars $=100 \mu \mathrm{m}$; details $=50$ $\mu \mathrm{m}$.

Características anatómicas de la madera de raíz de Erythroxylum tortuosum (A-C) y Copaifera langsdorffii (D-F). Barras = $100 \mu \mathrm{m}$; detalles $=50 \mu \mathrm{m}$.
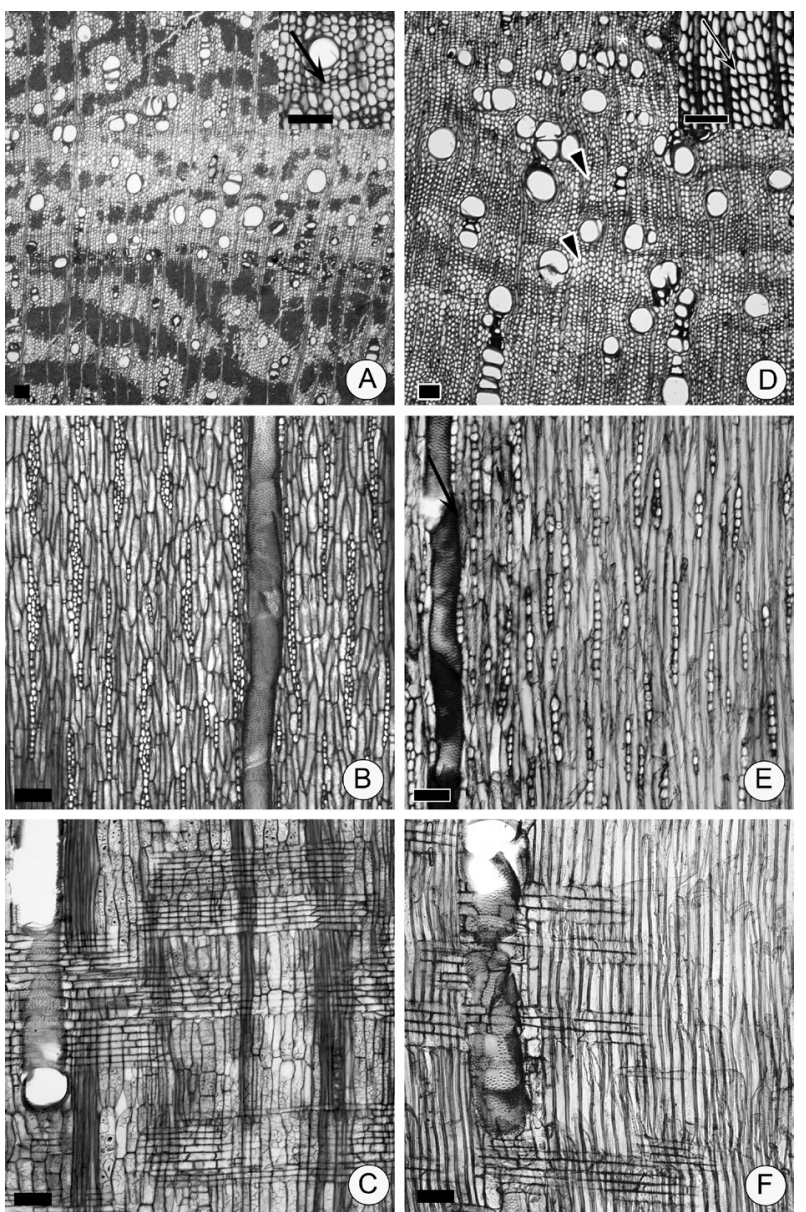

Figure 3. Root wood anatomical features of Anadenanthera peregrina var. falcata (A-C) and Stryphnodendron adstringens (D-F); parenchyma-like fiber bands alternating with ordinary fibers (arrow head); arrows point growth ring in A and D, detail. Scale bars $=100 \mu \mathrm{m}$; details $=50 \mu \mathrm{m}$.

Características anatómicas de la madera de raíz de Anadenanthera peregrina var. falcata (A-C) y Stryphnodendron adstringens (D-F). Barras $=100 \mu \mathrm{m}$; detalles $=50 \mu \mathrm{m}$. 
borders to apparently simple, rounded; deposits. Fibers: simple to minutely bordered pits; very thick-walled; 1311 $\mu \mathrm{m}(2197 / 681 \mathrm{SD}=340)$ in length; gelatinous fibers in small groups, sometimes forming bands intercalating with the axial parenchyma. Axial parenchyma: predominantly in bands more than three cells wide, long confluent, few short confluent and lozenge (figure 3A); 2 to 4 cells per parenchyma strand; great quantity of starch. Rays: 1 to 3 ray cells in width (figure $3 \mathrm{~B}) ; 195 \mu \mathrm{m}(442 / 92 \mathrm{SD}=68)$ tall, $28 \mu \mathrm{m}(47 / 9 \mathrm{SD}=8)$ wide, $6 / \mathrm{mm}(12 / 4 \mathrm{SD}=2)$; all ray cells procumbent (figure $3 \mathrm{C}$ ). Inorganic inclusions: prismatic crystals in chambered axial parenchyma cells and in fibers.

Stryphnodendron adstringens. Growth rings: poorly marked by flattened latewood fibers (figure 3D, detail). Vessels: solitary and multiples (figure 3D); $351 \mu \mathrm{m}(521 / 190$ $\mathrm{SD}=81)$ in length, 11 per square millimeter $\left(\mathrm{mm}^{-2}\right)(34 / 1$ $\mathrm{SD}=7), 127 \mu \mathrm{m}(184 / 78 \mathrm{SD}=24)$ in tangential diameter; simple perforation plate; intervessel pits alternate, circular and vestured; vessel-ray pits similar to intervessel pits in size and shape; deposits. Fibers: thin-walled; $639 \mu \mathrm{m}$ (884/441 SD = 112) in length; with simple to minutely bordered pits; septate; parenchyma-like fiber bands alternating with ordinary fibers (figure 3D, arrow head). Axial parenchyma: vasicentric and few lozenge (figure 3D); 2 to 4 cells per parenchyma strand. Rays: uniseriate and few locally biseriate (figure 3E); $364 \mu \mathrm{m}(748 / 169 \mathrm{SD}=155)$ tall, $36 \mu \mathrm{m}(67 / 13 \mathrm{SD}=17)$ wide, $6 / \mathrm{mm}(10 / 2 \mathrm{SD}=2)$; all ray cells procumbent, and few body ray cells procumbent with one row of upright and/or square marginal cells (figure 3F). Inorganic inclusions: prismatic crystals in chambered fibers. Pith flecks: present (figure 8D).

Ocotea corymbosa. Growth rings: marked by radially flattened latewood fibers (figure 4A, detail). Vessels: diffuse-porous; solitary and multiples (figure 4A); $613 \mu \mathrm{m}(1737 / 233 \mathrm{SD}=319)$ in length, 13 per square millimeter $\left(\mathrm{mm}^{-2}\right)(24 / 4 \mathrm{SD}=4), 117 \mu \mathrm{m}(216 / 63 \mathrm{SD}$ $=29$ ) in tangential diameter; simple perforation plates; intervessel pits alternate, circular; vessel-ray pits with many reduced borders to apparently simple, pits rounded, horizontal to vertical, and two types in the same ray cell; tyloses. Fibers: thin-walled; $1000 \mu \mathrm{m}(1462 / 624 \mathrm{SD}=$ 222 ) in length; simple to minutely bordered pits; septate; parenchyma-like fiber bands alternating with ordinary fibers (figure 4A, arrow head). Axial parenchyma: scanty paratracheal (figure 4A); 3 to 7 cells per parenchyma strand; few vasicentric. Rays: 1 to 3 , and few up to 6 cells wide (figure 4B); $491 \mu \mathrm{m}(972 / 176 \mathrm{SD}=180)$ tall, 54 $\mu \mathrm{m}(84 / 27 \mathrm{SD}=12)$ wide, $6 / \mathrm{mm}(8 / 3 \mathrm{SD}=1)$; body ray cells procumbent with one row upright and/or square, and few 2-4 rows; rays with procumbent, square (figure 4C) and upright cells mixed throughout the ray. Secretory elements: oil cells associated with ray parenchyma and fibers (figure $4 \mathrm{~B}$ and $\mathrm{C}$, arrows).
Eriotheca gracilipes. Growth rings: poorly marked by flattened latewood fibers (figure 4D). Vessels: diffuse porosity; solitary and multiple (figure 4D); $362 \mu \mathrm{m}(549 / 204 \mathrm{SD}$ $=66)$ in length, 2 per square millimeter $\left(\mathrm{mm}^{-2}\right)(6 / 0 \mathrm{SD}=$ 1), $174 \mu \mathrm{m}(266 / 93 \mathrm{SD}=39)$ in tangential diameter; simple perforation plate; intervessel pits alternate, circular; vessel-ray pits with many reduced borders to apparently simple, rounded and similar to intervessel pits in size and shape; tyloses. Fibers: few fibers (very thick-walled) embedded in parenchyma cells; $1784 \mu \mathrm{m}$ (3996/975 SD $=464$ ) in length; with distinctly bordered pits (less than $3 \mu \mathrm{m})$; septate. Axial parenchyma: apparently in bands given the few fibers (figure 4D); 2 to 5 cells per parenchyma strand. Rays: few 1 to 3 and mostly wider than 10 -seriate by the relative absence of fibers (figure 4E); sheath cells (figure 4E, arrow); with procumbent, square and upright

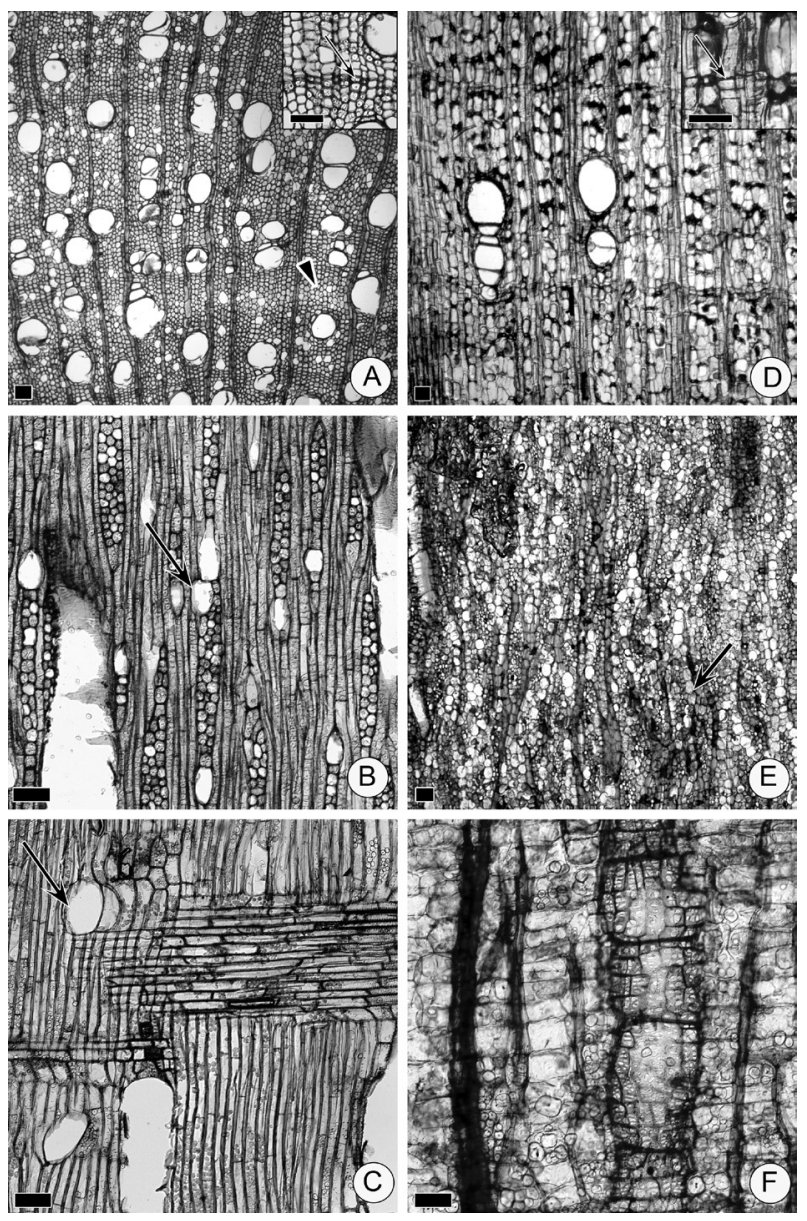

Figure 4. Root wood anatomical features of Ocotea corymbosa (A-C); parenchyma-like fiber bands alternating with ordinary fibers (arrow head) (A); and Eriotheca gracilipes (D-F); arrows point growth ring in $\mathrm{A}$ and $\mathrm{D}$, detail. Scale bars $=100 \mu \mathrm{m}$; details $=50 \mu \mathrm{m}$.

Características anatómicas de la madera de raíz de Ocotea corymbosa (A-C) y Eriotheca gracilipes (D-F). Barras $=100 \mu \mathrm{m}$; detalles $=50 \mu \mathrm{m}$. 
cells mixed throughout the ray (figure $4 \mathrm{~F}$ ); perforated ray cells. Ray measurements in the root were not performed due to difficulty in visualizing the ray cells that overlapped with the parenchyma cells that occur on a large scale, associated with the tiny proportion of fibers and vessels. Inorganic inclusions.

Miconia albicans. Growth rings: marked by thick-walled and radially flattened latewood fibers (figure 5A, detail). Vessels: diffuse porosity; solitary and multiple (figure 5A); $398 \mu \mathrm{m}(1233 / 129 \mathrm{SD}=203)$ in length, 41 per square millimeter $\left(\mathrm{mm}^{-2}\right)(66 / 20 \mathrm{SD}=8), 37 \mu \mathrm{m}(129 / 13 \mathrm{SD}=36)$ in tangential diameter; simple perforation plate; intervessel pits alternate, circular and vestured; vessel-ray pits similar to intervessel pits in size and shape; deposits. Fibers: very thin- to thick-walled; septate; $1300 \mu \mathrm{m}(2239 / 769 \mathrm{SD}=297)$
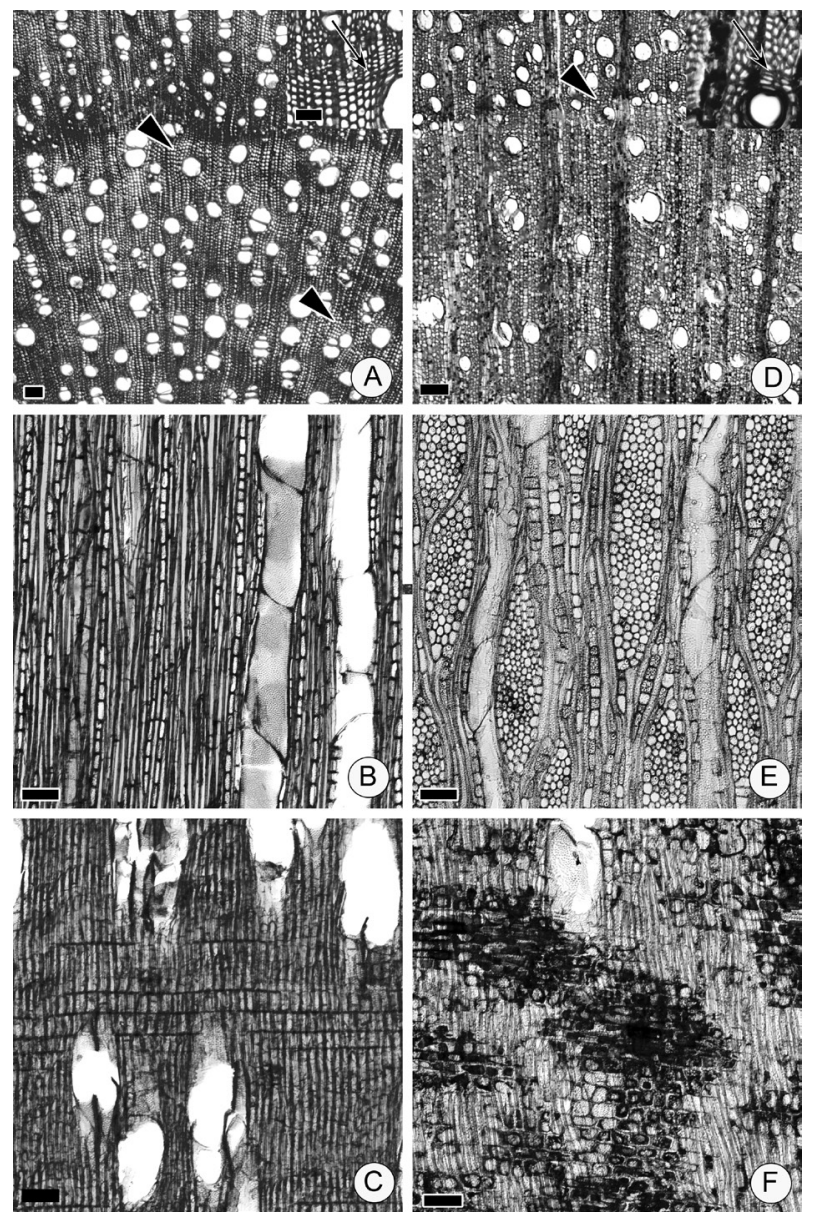

Figure 5. Root wood anatomical features of Miconia albicans (A-C); parenchyma-like fiber bands alternating with ordinary fibers (arrow head) (A); and Myrcia bella (D-F); arrows point growth ring in $\mathrm{A}$ and $\mathrm{D}$, detail wood. Scale bars $=100 \mu \mathrm{m}$; details $=$ $50 \mu \mathrm{m}$.

Características anatómicas de la madera de raíz de Miconia albicans (A-C) and y Myrcia bella (D-F). Barras $=100 \mu \mathrm{m}$; detalles = $50 \mu \mathrm{m}$. length; parenchyma-like fiber bands alternating with ordinary fibers (figure 5A); gelatinous fibers. Axial parenchyma: scanty (figure $5 \mathrm{~A}$ ); 3 to 5 cells per parenchyma strand; $488 \mu \mathrm{m}(658 / 321 \mathrm{SD}=83)$ tall, $24 \mu \mathrm{m}(32 / 18 \mathrm{SD}=$ 3 ) wide, $7 / \mathrm{mm}(11 / 5 \mathrm{SD}=1)$; Rays: exclusively uniseriate (figure 5B); all ray cells upright and/or square (figure 5C).

Myrcia bella. Growth rings: marked by thick-walled and radially flattened latewood fibers (figure 5D, arrow head). Vessels: diffuse porosity; exclusively solitary (figure 5D); $632 \mu \mathrm{m}(797 / 451 \mathrm{SD}=86)$ in length, 6 per square millimeter $\left(\mathrm{mm}^{-2}\right)(11 / 2 \mathrm{SD}=2), 82 \mu \mathrm{m}(123 / 58 \mathrm{SD}=17)$ in tangential diameter; simple perforation plate; intervessel pits alternate, circular and vestured; vessel-ray pits similar to intervessel pits in size and shape. Fibers: with distinctly bordered pits (figure 8E); thin- to thick-walled; $1085 \mu \mathrm{m}$ $(1355 / 833 \mathrm{SD}=150)$ in length; few with septa. Axial parenchyma: diffuse-in-aggregates and scanty (figure 5D); 2 to 6 cells per parenchyma strand. Rays: uniseriate and 1 to 7 cells wide, with two distinct sizes (figure $5 \mathrm{E}$ ); $455 \mu \mathrm{m}$ $(577 / 341 \mathrm{SD}=69)$ tall, $60 \mu \mathrm{m}(79 / 46 \mathrm{SD}=9)$ wide, $8 / \mathrm{mm}$ $(10 / 5 \mathrm{SD}=1)$, measurements refer to multiseriate rays; body ray cells procumbent with mostly 2 to more than 4 rows of upright and/or square marginal cells; all ray cells upright and/or square (figure 5F); perforated ray cells. Aggregated rays.

Eugenia aurata. Growth rings: marked by fiber zones and higher frequency of vessels adjacent to the growth rings (figure 6A, detail). Vessels: diffuse porosity; solitary and few multiple (figure $6 \mathrm{~A}) ; 424 \mu \mathrm{m}(572 / 287 \mathrm{SD}=79)$ in length, 127 per square millimeter $\left(\mathrm{mm}^{-2}\right)(165 / 67 \mathrm{SD}=$ 26), $36 \mu \mathrm{m}(49 / 28 \mathrm{SD}=5)$ in tangential diameter; simple perforation plate; intervessel pits alternate, circular, vestured; vessel-ray pits similar to intervessel pits in size and shape; few deposits. Fibers: with distinctly bordered pits (figure 8F); very thick-walled; $951 \mu \mathrm{m}(1163 / 678 \mathrm{SD}=$ $124)$ in length; gelatinous fibers. Axial parenchyma: diffuse-in-aggregates forming lines and diffuse (figure 6A); predominantly 4 to 8 cells, and some more than 8 cells per parenchyma strand. Rays: 1 to 3 ray cells in width (figure 6B); $298 \mu \mathrm{m}(425 / 209 \mathrm{SD}=45)$ tall, $38 \mu \mathrm{m}(49 / 25 \mathrm{SD}=5)$ wide, $12 / \mathrm{mm}(16 / 8 \mathrm{SD}=2)$; predominantly with body ray cells procumbent with over 4 rows of upright and/or square marginal cells; few having all one row of upright and/or square marginal cells; and square and upright cells mixed throughout the ray (figure 6C). Inorganic inclusions: prismatic crystals in enlarged cells.

Eugenia punicifolia. Growth rings: marked by fiber zones (figure 6D, detail). Vessels: diffuse porosity; solitary and few multiple (figure 6D); $519 \mu \mathrm{m}(767 / 233 \mathrm{SD}=126)$ in length, 86 per square millimeter $\left(\mathrm{mm}^{-2}\right)(146 / 46 \mathrm{SD}=22)$, $43 \mu \mathrm{m}(58 / 24 \mathrm{SD}=7)$ in tangential diameter; intervessel pits alternate, circular and vestured; vessel-ray pits similar to intervessel pits in size and shape; deposits. Fibers: with 
distinctly bordered pits (figure $8 \mathrm{G}$ ); very thick-walled; $788 \mu \mathrm{m}(1182 / 591 \mathrm{SD}=122)$ in length. Axial parenchyma: diffuse-in-aggregates forming lines (figure 6D); 4 to 8 cells per parenchyma strand. Rays: 1 to 3 cells wide (figure $6 \mathrm{E}) ; 434 \mu \mathrm{m}(652 / 276 \mathrm{SD}=85)$ tall, $46 \mu \mathrm{m}(68 / 24 \mathrm{SD}=$ 8 ) wide, $7 / \mathrm{mm}(11 / 4 \mathrm{SD}=1)$; with uniseriate portion as wide as multiseriate portions (figure 6E); body ray cells procumbent with one to over 4 rows of upright and/or square marginal cells (figure 6F), and rays with procumbent, square and upright cells mixed throughout the ray; perforated ray cells.

Ouratea spectabilis. Growth rings: marked by fiber zones (figure 7A, detail). Vessels: diffuse porosity; exclusively solitary (figure 7A); $547 \mu \mathrm{m}(773 / 334 \mathrm{SD}=122)$ in length, 13 per square millimeter $\left(\mathrm{mm}^{-2}\right)(19 / 9 \mathrm{SD}=2), 55 \mu \mathrm{m}$ $(69 / 41 \mathrm{SD}=7)$ in tangential diameter; simple perforation plate; intervessel pits alternate, circular; vessel-ray pits si-
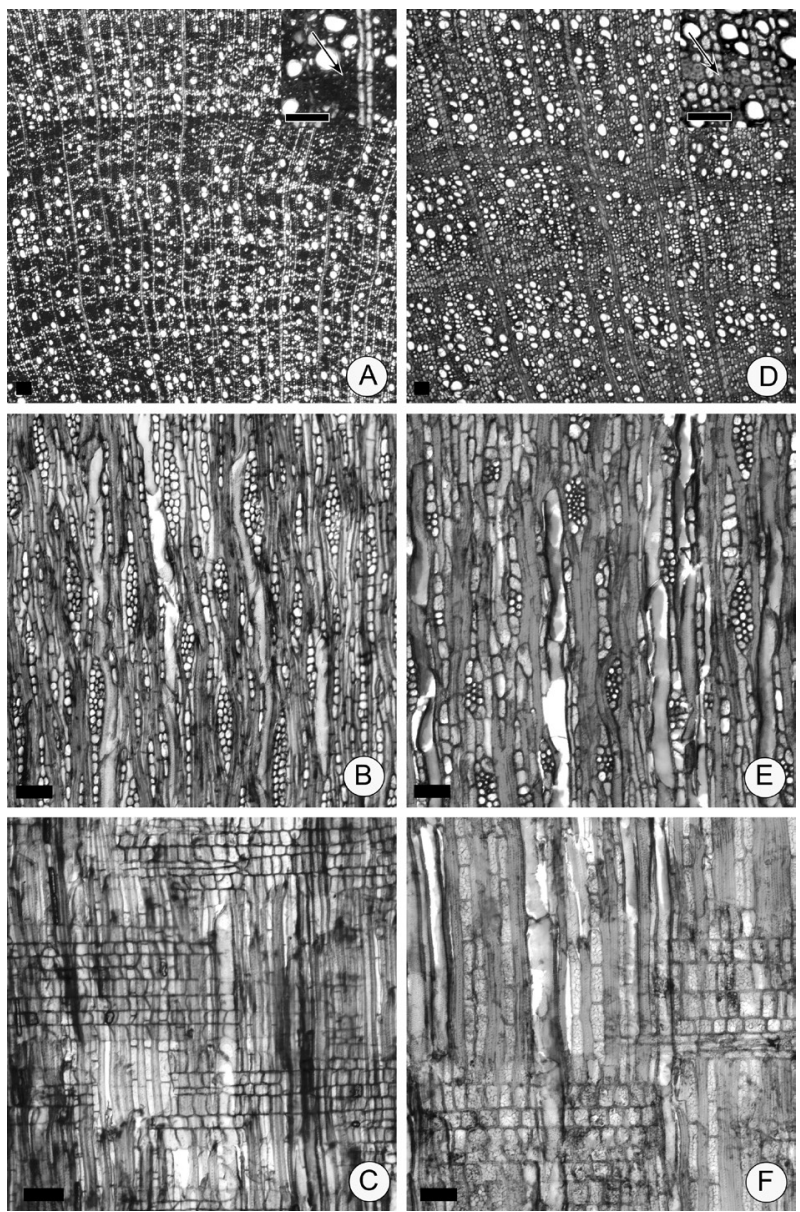

Figure 6. Root wood anatomical features of Eugenia aurata (AC) and Eugenia punicifolia (D-F); arrows point growth ring in A and $\mathrm{D}$, detail. Scale bars $=100 \mu \mathrm{m}$; details $=50 \mu \mathrm{m}$.

Características anatómicas de la madera de raíz de Eugenia aurata (A-C) y Eugenia punicifolia (D-F). Barras $=100 \mu \mathrm{m}$; detalles $=$ $50 \mu \mathrm{m}$. milar to intervessel pits in size and shape; few deposits. Fibers: with distinctly bordered pits (figure 8I); very thickwalled; few septate (figure $8 \mathrm{H}) ; 1331 \mu \mathrm{m}(1832 / 888 \mathrm{SD}$ $=249$ ) in length. Axial parenchyma: diffuse and diffusein-aggregates, scanty paratracheal (figure 7A); 2 to 6 cells per parenchyma strand. Rays: 1-seriate and larger rays to 6 cells wide (figure $7 \mathrm{~B}) ; 1058 \mu \mathrm{m}(1796 / 605 \mathrm{SD}=257)$ tall, $101 \mu \mathrm{m}(153 / 60 \mathrm{SD}=19)$ wide, $5 / \mathrm{mm}(7 / 3 \mathrm{SD}=1)$; of two distinct sizes, measurements refer to multiseriate rays; with procumbent, square and upright cells mixed throughout the ray (figure 7C); all ray cells upright and /or square. Inorganic inclusions: prismatic crystals in square ray cells.

Vochysia tucanorum. Growth rings: indistinct. Vessels: diffuse porosity; solitary and multiple (figure 7D); $465 \mu \mathrm{m}$ $(707 / 274 \mathrm{SD}=112)$ in length, 11 per square millimeter $\left(\mathrm{mm}^{-2}\right)(25 / 6 \mathrm{SD}=4), 155 \mu \mathrm{m}(232 / 96 \mathrm{SD}=31)$ in tangential diameter; simple perforation plate; intervessel pits
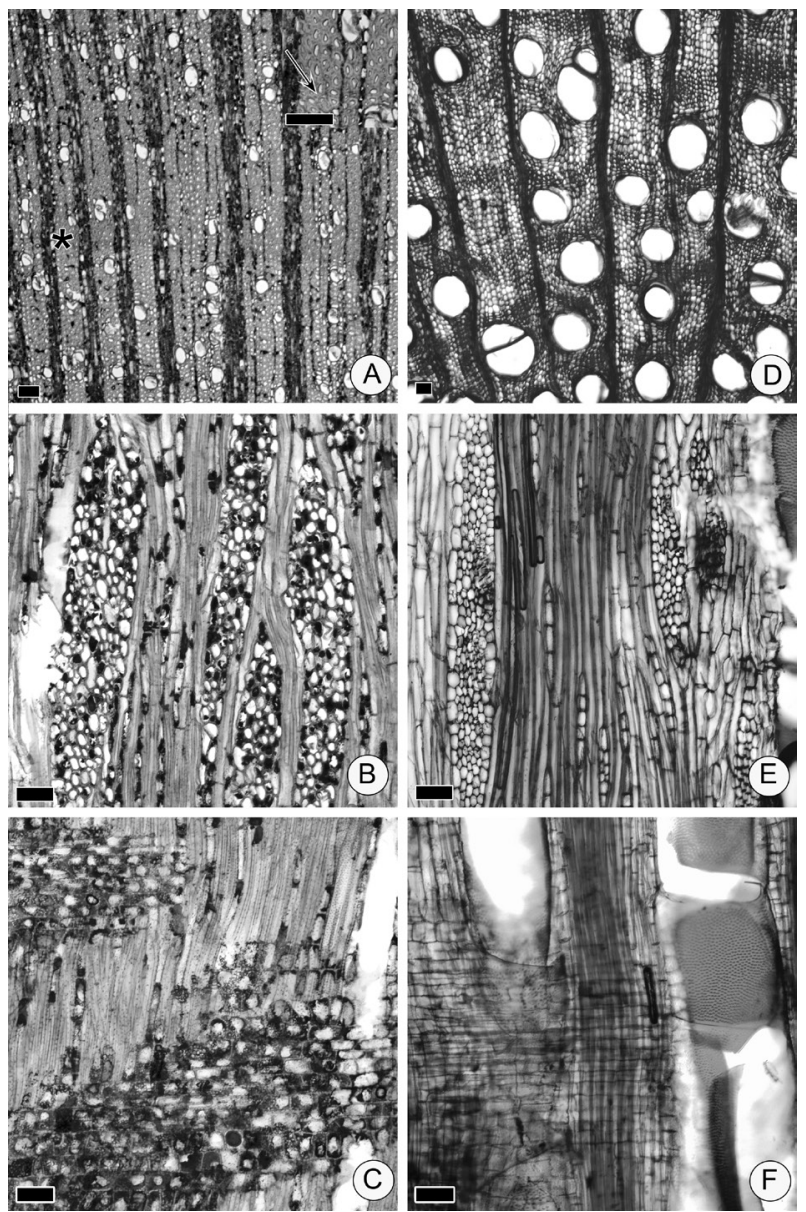

Figure 7. Root wood anatomical features of Ouratea spectabilis (A-C) arrow points growth ring in (A), detail and Vochysia tucanorum (D-F). Scale bars $=100 \mu \mathrm{m}$; details $=50 \mu \mathrm{m}$.

Características anatómicas de la madera de raíz de Ouratea spectabilis (A-C) y Vochysia tucanorum (D-F). Barras $=100 \mu \mathrm{m}$; detalles $=50 \mu \mathrm{m}$. 
alternate, circular, vestured; vessel-ray pits similar to intervessel pits in size and shape; deposits. Fibers: with simple to minutely bordered pits; thin- to very thick-walled; septate; $1266 \mu \mathrm{m}(1578 / 758 \mathrm{SD}=228)$ in length. Axial parenchyma in bands more than 3 cells wide (figure 7D); 2 to 6 cells per parenchyma strand. Rays: 3 to 7 cells wide, few uniseriate (figure $7 \mathrm{E}) ; 937 \mu \mathrm{m}(1293 / 657 \mathrm{SD}=148)$ tall, $85 \mu \mathrm{m}$ $(125 / 46 \mathrm{SD}=18)$ wide, $4 / \mathrm{mm}(6 / 2 \mathrm{SD}=1)$ of two distinct sizes, measurements refer to multiseriate rays; sheath cells (figure 7E); body ray cells procumbent with one to 4 rows of upright and/or square marginal cells (figure 7F); all rays upright and/or square, and rays with procumbent, square and upright cells mixed throughout the ray.
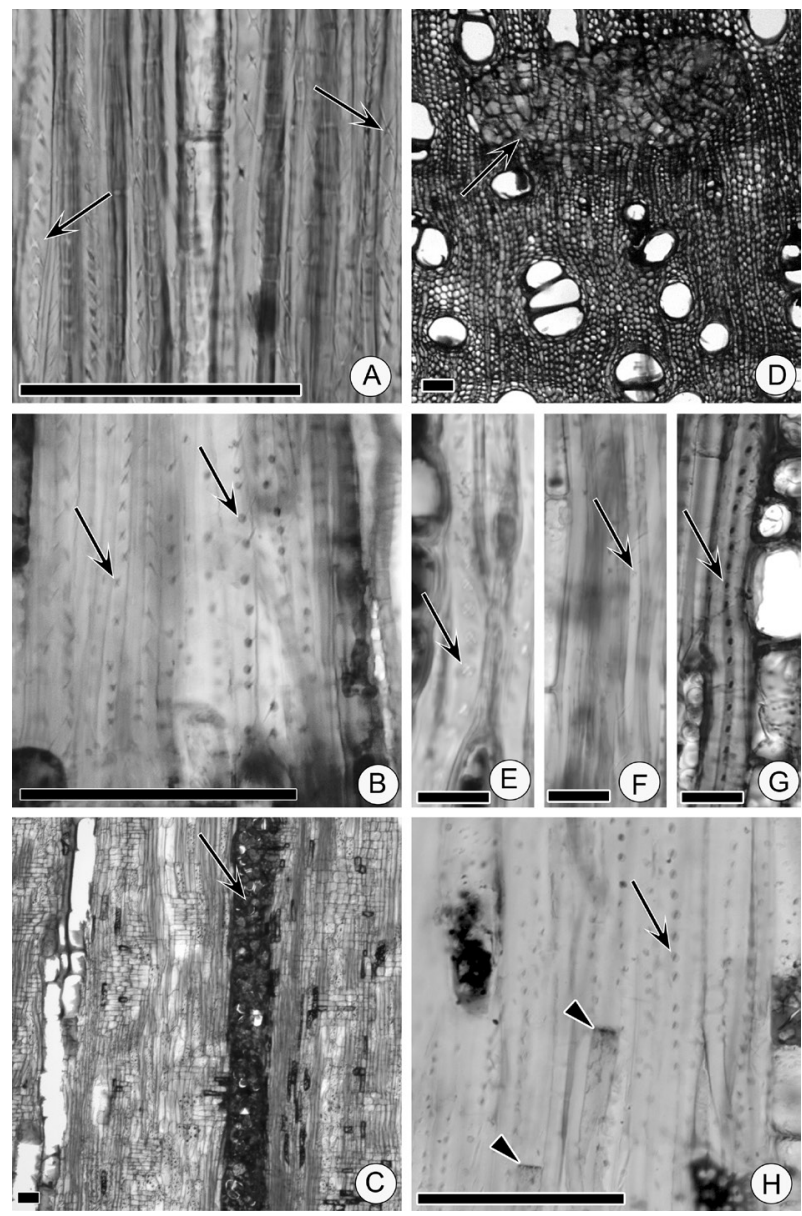

Figure 8. Root wood anatomical features. Xylopia aromatica fiber pits (A) in TLS, arrows; detail in macerate; Erythroxylum tortuosum fiber pits in RLS (B), arrows; Copaifera langsdorffii axial canal in RLS (C), arrow; Stryphnodendron adstringens pith flecks (arrow) TS (D); fiber pits (arrow) in: Myrcia bella in TLS (E), Eugenia aurata in RLS (F), Eugenia punicifolia in TLS (G), Ouratea spectabilis and septate fiber (arrow head) (H) in RLS. Scale bars A-D;H $=100 \mu \mathrm{m} ; \mathrm{E}-\mathrm{G}$ and details $=25 \mu \mathrm{m}$.

Características anatómicas de la madera de raíz de Ouratea spectabilis (A-C) y Vochysia tucanorum (D-F). Barras A-D; $\mathrm{H}=100 \mu \mathrm{m}$; E-G y detalles $=25 \mu \mathrm{m}$.

\section{DISCUSSION}

Qualitative wood anatomical descriptions of roots were compared with literature for main stem or branch wood for the same species and, when possible, with Cerrado species from São Paulo, using the work of Sonsin et al. (2014) and InsideWood, a Web resource (2016), containing descriptions of wood anatomy from different biomes of Brazil, or other countries, and many authors.

According to Sonsin et al. (2014) studying stem wood, growth rings are not as easy to interpret as they are in temperate woods. The authors also stand out that the growth ring markers are more easily observed at low magnification with the naked eye or using a hand lens than under the microscope. While analyzing roots we noticed growth rings, in general, are harder to distinguish than the main stem or branch because of the quantity and distribution of axial parenchyma, which consequently complicated description. In some cases, there were islands of fibers among the axial parenchyma cells as in Anadenanthera peregrina var. falcata and Vochysia tucanorum, very different from the branch or main stem (see Sonsin et al. 2014 and InsideWood).

The higher quantity of axial parenchyma observed in roots and the presence of septate fibers in some roots (Erythroxyllum tortuosum, Sthyphnodendron adstringens, Eriotheca gracilipes, Ouratea spectabilis and Vochysia tucanorum species), although not in stem or branches (see Sonsin et al. 2014 and InsideWood), may indicate an evolutionary adjustment to provide for more storage tissue (Dickson 2000).

The root wood anatomical data of Xylopia aromatica were similar to those cited by Detienne and Jacquet (1983) at stem wood; however, the axial parenchyma was not as well defined as that in stem wood, essentially because of the high quantity of axial parenchyma in root wood where lines are not clearly scalariform. Furthermore; ray composition is highly varied.

For Handroanthus ochraceus, we observed growth rings well marked by marginal bands of axial parenchyma, different from the observation of Teixeira et al. (2003), who reported indistinct growth rings at stem level. Again, in this species, we observed variation in the quantity of axial parenchyma, mostly very large bands more than 10 cells wide. Even, the storied structure was not always regular.

Generally, the anatomical root features of Erythroxylum tortuosum were similar to those of stem wood (see Sonsin et al. 2014), however, the fibers are very thick-walled in this study, while in Sonsin et al. (2014), the fibers were thin- to thick-walled. The author noted variation in ray composition, whereas in the present study, we noted body ray cells procumbent with 2-4 rows of upright and/or square marginal cells. In addition, we reported only square and upright cells mixed throughout the ray, whereas Sonsin et al. (2014) reported procumbent, square and upright 

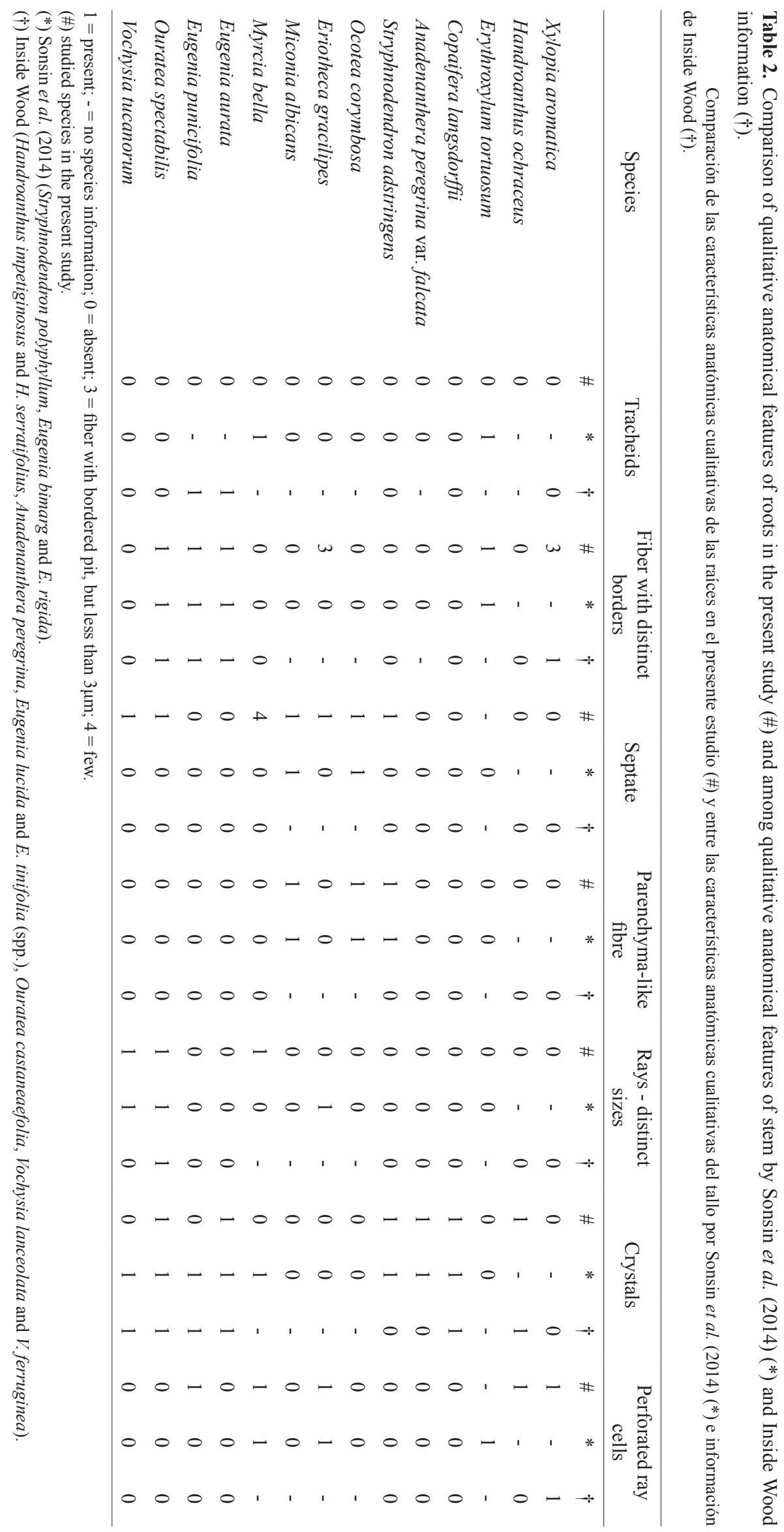
cells mixed throughout the ray. Finally, we observed prismatic crystals in chambered axial parenchyma cells.

The general anatomical features of Copaifera langsdorffii were similar to those noted in literature for main stem and branch (Richter and Dallwitz 2000, Sonsin et al. 2014), nonetheless we observed variation in ray composition with all ray cells procumbent and body ray cells procumbent with one to two rows of upright and/or square marginal cells. In contrast, only one or two rows of upright and/or marginal cells have, thus far, been noted in the literature.

For Anadenanthera peregrina var. falcata, we observed a great variation in the quantity of paratracheal parenchyma, either in bands or long confluent, with fibers appearing to be embedded within axial parenchyma cells when compared to stem studied by Sonsin et al. (2014).

For Stryphnodendron adstringens, the main difference observed was the presence of parenchyma-like fiber bands alternating with ordinary fibers when compared to root wood studied by Goulart et al. (2015) and wood stem studied by Montefusco (2005). In the present study, fibers were septate. According to Goulart et al. (2015), prismatic crystals were observed in fibers and in chambered axial parenchyma cells.

For Ocotea corymbosa, we observed variation in ray composition and thickness of fibers when compared to Paula et al. (2000), studying stem wood of gallery forest species. Our observations are more in line with those of Sonsin et al. (2014) in both axial and radial parenchyma.

For Eriotheca gracilipes, we observed a few very thickwalled fibers which seem to be embedded in parenchyma cells that occur in large bands, not diffuse-in-aggregates, forming lines, as in the stem wood observed by Sonsin et al. (2014). Also, growth rings were very difficult to see in roots in this study, while in Longui et al. (2012) and Marcati et al. (2006), thick-walled and radially flattened latewood fibers were noted at the main stem and branch.

The anatomical description of Miconia albicans was similar to that of Sonsin et al. (2014) at stem level.

Compared to Sonsin et al. (2014), the description of Myrcia bella differed only in the presence of a few septate fibers present in roots, while tracheids were only observed in branches.

We did not find a basis for comparison of either Eugenia aurata or E. punicifolia. However, apart from variation in the presence or absence and size of prismatic crystals, the anatomical features are like the genera described by Soffiatti and Angyalossy-Alfonso (1999) and Sonsin et al. (2014).

For Ouratea spectabilis, the fibers were thicker in roots compared to Sonsin et al. (2014). We observed variation in ray composition, with procumbent, square and upright cells mixed throughout the ray in both papers, we also found all ray cells to be upright and/or square.

We did not observe the presence of growth rings in Vochysia tucanorum, nevertheless we did note septate fibers, whereas Sonsin et al. (2014) did not. The high quantity of axial parenchyma, which forms sinuous bands, was variable, being higher in roots, while in branches, paratracheal parenchyma varied, with less quantity, though. We saw variation in ray composition when compared to Sonsin et al. (2014), with more rows and rays with mixed up cells. Paula et al. (2000) observed only homogeneous rays and included phloem, which was not observed in the present work or that of Sonsin et al. (2014).

\section{CONCLUSIONS}

In general, the quantity and distribution of axial parenchyma of root wood are very different from that of the main stem, being higher in roots, in which we concluded that the roots main function is not focused on support, but on storage. This same quantity of axial parenchyma in root wood made it difficult to describe; growth rings are hard to distinguish.

\section{ACKNOWLEDGMENTS}

The authors thank Yara R. W. Vianello for laboratory assistance and Antônio C. G. de Melo for fieldwork. We also thank the Conselho Nacional de Desenvolvimento Científico e Tecnológico - CNPq (National Council for Scientific and Technological Development - 145829/20120 and 121304/2013-2) for grants to Gabriela T. Pires and the Fundação do Desenvolvimento Administrativo (FUNDAP) for the grant to Juliana Arce de Goes Pacheco.

\section{REFERENCES}

Bukatsch F. 1972. Bermerkungen zur Doppelfärbung AstrablauSafranin. Mikrokosmos 61(8): 255.

Caldwell MM, TE Dawson, JH Richards. 1998. Hydraulic lift: consequences of water efflux from the roots of plants. Oecologia 113(2):151-161.

CEPAGRI (Centro de Pesquisas Meteorológicas e Climáticas Aplicadas a Agricultura, BR). Clima dos Municípios Paulistas. Acessed 18 Sep. 2016. Available in http://www. cpa. unicamp.br/outras-informacoes/clima-dos-municipiospaulistas.html

Detienne P, P Jacquet. 1983. Atlas d'identification des bois de l'amazonie et des regions voiseines. Nogent-sur-Marne, France. Centre Technique Forestier Tropical. 640 p.

Fortunel C, J Ruelle, J Beauchene, PVA Fine, C Baraloto. 2014. Wood specific gravity and anatomy of branches and roots in 113 Amazonian rainforest tree species across environmental gradients. New Phytologist 202(1):79-94. doi/10.1111/ nph. 12632

Franklin G. 1945. Preparations of thin sections of synthetic resins and wood - resin composites and a new macerating method for wood. Nature 155:51.

Goulart SL, AO Ribeiro, FA Mori, NF Almeida, CO Assis. 2015. Anatomia do lenho de raiz, tronco e galho de barbatimão (Stryphnodendron adstringens (Mart) Coville). Cerne 21(2):329-338. doi.org/10.1590/01047760201521021627 
Goulart SL, CR Marcati. 2008. Anatomia comparada do lenho em raiz e caule de Lippia salviifolia Cham. (Verbenaceae). Revista Brasileira de Botânica 31(2):263-275.

IAWA Committee. 1989. IAWA list of microscopic features for hardwood identification. IAWA Bulletin 10(2):219-332.

Inside Wood - NC State University. accessed 24 Aug. 2016. Available in http://insidewood.lib.ncsu. edu

Kraus JE, M Arduin. 1997. Manual básico de métodos em morfologia vegetal. Rio de Janeiro, Brazil. EDUR. 198 p.

Krause C, S Rossi, M Thibeault-Martel, P-Y. Plourde. 2010. Relationships of climate and cell features in stems and roots of black spruce and balsam fir. Annals of Forest Science 67(4):402.

Longui EL, KS Rajput, AC Galvão de Melo, LA Alves, CB Nascimento. 2017. Root to branch wood anatomical variation and its influence on hydraulic conductivity in five Brazilian Cerrado species. Bosque 38(1): 183-193. DOI: 10.4067/ $\underline{\text { S0717-92002017000100018 }}$

Longui EL, RABG Silva, D Romeiro, IL Lima, SMB Florsheim, ACG Melo. 2012. Root-branch anatomical investigation of Eriotheca gracilipes young trees: a biomechanical and ecological approach. Scientia Forestalis 40(93):23-33.

Machado SR, Angyalossy-Alfonso V, BL Morretes. 1997. Comparative wood anatomy of root and stem in Styrax camporum (Styracaceae). IAWA Journal 18(1): 13-25. DOI: 10.1163/22941932-90001454

Machado SR, RA Rodella, V Angyalossy, CR Marcati. 2007. Structural variations in root and stem wood of Styrax (Styracaceae) from Brazilian forest and Cerrado. IAWA Journal 28(2): 173-188.

Maeght JL, Rewald B, Pierret A. 2013. How to study deep rootsand why it matters. Functional Plant Ecology 4(299): 1-15. DOI: $10.3389 /$ fpls.2013.00299

Marcati CR, J Sonsin-Oliveira, SR Machado. 2006. Growth rings in Cerrado woody species: occurrence and anatomical markers. Biota Neotropica v6(3). http://www.biotaneotropica. org.br/ v6n3/pt/abstract?article+bn 00206032006

Marcati CR, LR Longo, A Wiedenhoeft, CF Barros. 2014. Comparative wood anatomy of root and stem of Citharexylum myrianthum (Verbenaceae). Rodriguésia 65(3): 567-576.

Montefusco ARG. 2005. Anatomia Ecológica do Lenho de Stryphnodendron adstringens (Mart.) Coville (Leguminosae), Barbatimão, no Parque Estadual do Cerrado - Jaguariaíva-PR. Cutitiba, Brasil. Dissertação de Mestre em Ciências Florestais. Universidade Federal do Paraná. 105 p.

Paula JE, FG Silva-Júnior, APP Silva. 2000. Caracterização anatômica de madeiras nativas de matas ciliares do centro-oeste brasileiro. Scientia Forestalis 58:73-89.

Pratt RB, AL Jacobse, FW Ewer, SD Davis. 2007. Relationships among xylem transport, biomechanics and storage in stems and roots of nine Rhamnaceae species of the California chaparral. New Phytologist 174(4):787-798.

Ratter JA, JF Ribeiro, S Bridgewater. 1997. The Brazilian Cerrado vegetation and threats to its biodiversity. Annals of Botany 80(3): 223-230.

Richter HG, MJ Dallwitz. 2000 onwards. Commercial timbers: descriptions, illustrations, identification, and information retrieval. In English, French, German, and Spanish. Version: 25th June 2009. Acessed 5 Set. 2016. Available in http://delta-intkey.com

Soffiatti P, V Angyalossy-Alfonso. 1999. Estudo anatômico comparativo do lenho e da casca de duas espécies de Eugenia L. (Myrtaceae). Revista Brasileira de Botânica 22(2): 175184.

Sonsin JO, P Gasson, SR Machado, C Caum, CR Marcati. 2014. Atlas da diversidade de madeiras do Cerrado paulista. Botucatu, Brasil. Fundação de Estudos e Pesquisas Agrícolas e Florestais. 423 p.

Teixeira LL, PP Matos, Paulo César Botosso, RA Seitz, SM Salis. 2003. Anatomia de madeiras do Pantanal Mato-Grossense - Características microscópicas. Colombo, Brasil. Embrapa Florestas. 182 p. 
